\title{
K VÝVOJI ČESKÉ CHRÁMOVÉ HUDBY VE 20. STOLETÍ
}

\section{Úvodem}

Pojednat o vývoji české chrámové hudby ve 20. století není úkol snadný. ${ }^{1} \mathrm{Li}$ turgická hudba, patrně $\mathrm{z}$ důvodu své primární funkčnosti, nestála a nestojí v centru pozornosti hudebních historikủ. ${ }^{2}$ Hudební produkce většiny biskupských chrámů, natož kostelů farních a venkovských, nejsou dosud zpracovány. Také tisk informoval o hudebním dění na kůrech $\mathrm{v}$ průběhu minulého století velmi nevyrovnaně. Zatímco do roku 1948 se mohl badatel oprít o informace prezentované v místním tisku a zejména v časopise Cyril (založen 1874), následné dění až do roku 1989 nebylo veřejně reflektováno téměř vůbec. Výzkum tohoto období je založen na studiu kronik, případně „živé“ paměti farníků, hudebníků a kněží.

1 Tento text shrnuje výsledky autorčina výzkumu hudby v olomoucké katedrále (viz VIČAROVÁ, Eva. Hudba v olomoucké katedrále, 1872-1985, Olomouc: Univerzita Palackého, 2012.) a chrámové hudby v dalších olomouckých kostelích ve 20. století. Chrámovou hudbou je míněna liturgická hudba římsko-katolické církve, nikoliv duchovní hudba uváděná v kostelech na tzv. koncertech duchovní hudby. Ve studii bude také zohledněna ryze autonomní umělecká činnost chrámových těles. Text naopak rezignuje na hudební festivaly a koncerty, které se konaly ve zmíněných kostelech jakožto pronajatých koncertních prostorách, nebot' tato činnost se vlastních aktivit chrámových sborů nikterak netýkala.

Stěžejní roli ve výzkumu sehrál Jiří Sehnal, viz SEHNAL, Jiří. Chrámová hudba na Moravě od cyrilské reformy do současnosti. Opus musicum, 2001, roč. 33, č. 4, s. 4-18; SEHNAL, Jiří. Stručný přehled dějin katolické chrámové hudby. Rosice: Glorie, 1999; HLAVÁČEK, Petr. Hudba v chrámu Vzkříšení Páně ve Slavkově u Brna do poloviny 20. století. In Hudba v Olomouci a na střední Moravě II. Morava a svět: Umění v otevreném multikulturním prostoru. Eva Vičarová (ed.). Olomouc, 2008, s. 7-44; SILNÁ, Ingrid. Hudba ve farním kostele sv. Václava v Tovačově. Olomouc, 2009; SMUTNÝ, Pavel. Liturgická hudba a muzikologie. Opus musicum, 1996, roč. 28, č. 2, s. 61-63; a v neposlední řadě studenti Ústavu hudební vědy Filozofické fakulty Univerzity Karlovy v Praze: BAJER, Petr. Př́spěvek $k$ dějinám chrámové hudby v Čechách ve 2. polovině 20. století. Seminární práce, Ústav hudební vědy FF UK, Praha, 2005; NOVÁKOVÁ, Marcela. Katolická liturgická hudba v 50. letech 20. století. Seminární práce, Ústav hudební vědy FF UK, Praha, 2005; NOVÁKOVÁ, Marcela. Katolická liturgická hudba v kontextu hudebního vývoje a politických změn po druhé svètové válce. Diplomová práce, Ústav hudební vědy FF UK, Praha, 2008. 
Přestože se situace po pádu komunismu mírně zlepšila a příznivci chrámové hudby nalézají informace v odborných periodicích typu Varhanik (založen 2002) či Psalterium (2007), na internetu prostřednictvím Portálu duchovní hudby Společnosti pro duchovní hudbu nebo sdružení chrámových hudebníků Musica sacra, $\mathrm{k}$ vytvoření reprezentativního obrazu to stále nestačí. Cílem následujícího textu je představit hlavní vývojové mezníky, které se odrazily v repertoáru a organizačním provozu českých chrámových těles ve 20 . století.

\section{I.}

Církevní hudba jakožto svébytný hudební žánr a druh má za sebou pestrý vývoj. Pro dění ve 20 . století se stal velmi podnětným papežský list Pia X. Motu proprio Tra le sollecitudini (1903), ,zákoník právní hudby posvátné“, jímž kulminovaly snahy německých cecilianistů, ale i zastánců historického př́stupu o vnitřní očištění hudby při liturgii. ${ }^{3} \mathrm{~K}$ důsledkům papežského listu patřil mimo jiné také návrat $\mathrm{k}$ autentické podobě gregoriánského chorálu. Zjednodušená edice Kaspara Etta a později tzv. řezenská edice (Editio Ratisbonensis) Franze Xavera Haberla, jež vycházela v letech 1871-1881, byly opuštěny a naopak nic nebránilo solesmenským benediktinům založit Editio Vaticana, v níž vyšel Graduale Sacrosanctae Romanae Ecclesiae de tempore et de sanctis ss. D. n. Pii X. Pontificis Maximi jusuu restitutum et editum cui addita sunt festa novissima roku $1908 .{ }^{4}$

Tento typ hudby však zůstal v plné kompetenci chrámových zpěváků. K prostému lidu si gregoriánský chorál cestu nenalezl. Církevní obec se účastnila liturgického dění prostřednictvím zpěvu duchovních písní vydaných v Katolickém kancionálu Tomáše Bečáka (Olomouc 1847), kancionálu Ludvíka Holaina Plesy duchovní (Olomouc 1883) a později Cesta k věčné slávě (Brno 1912). ${ }^{5}$

Až do první světové války určovala u nás charakter liturgické hudby odnož německého cecilianismu, cyrilismus. Byly založeny desítky farních cyrilských jednot, které usilovaly o obrodu církevní hudby prostřednictvím gregoriánského chorálu, renesanční vokální polyfonie a cappella či skladeb německých cecilianistů, např. Petera Griesbachera (1864-1933), Johanna Georga Mettenleitera

3 Více viz: KIRSCH, Winfried. Caecilianismus. In Die Musik in Geschichte und Gegenwart. Sachteil, Bd. 2, 1995, s. 317-326; KÜFHABEROVÁ, Božena. Cecilianismus. In Slovník české hudební kultury. Jiř́ Fukač - Jiří Vysloužil (red.), Petr Macek (ed.). Praha: Editio Supraphon, 1997, s. 90; SMUTNÝ, Pavel. Historické kořeny cecilianismu. K významu reformního hnutí. Opus musicum, 1997, roč. 29, č. 3, s. 138-148.

4 Pandánem papežského listu z roku 1903 se staly konstituce Divini cultus Pia XI. z roku 1928, encykliky Pia XII. Mediator Dei (1947), Musicae sacrae disciplina (1955) a Instrukce o cirkevni hudbě a posvátné liturgii (1955).

$5 \quad$ Více viz SLAVICKÝ, Tomáš. K vývoji české kostelní písně v první polovině 20. století. In 70. výročie vydania Jednotného katolického spevnika. Zbornik prispevkov z muzikologickej konferencie. Trnava - Bratislava 2008, s. 78-101. 
(1812-1868), Franze Nekese (1844-1914), Johanna Gustava Eduarda Stehleho (1839-1915) či Franze Xavera Witta (1834-1888).

$\mathrm{K}$ domácím skladatelům, jejichž kompoziční styl vycházel z pravidel renesančního kontrapunktu, patřili František Zdeněk Skuherský (1830-1892), Josef Förster (1833-1907), Pavel Kř́žkovský (1820-1885) a př́slušníci Skuherského skladatelské školy, tedy Josef Cainer (1837-1910), František Hruška (18471889), Josef Nešvera (1842-1914), Karel Stecker (1861-1918), Josef Cyril Sychra (1859-1935) a Jan Evangelista Zelinka (1856-1935).

Mnoha kůrů se však cyrilská reforma církevní hudby vůbec nedotkla, a tak zde zaznívaly figurální mše Franze Bühlera (1760-1824), Antona Diabelliho (1781-1858), Karla Ludwiga Drobische (1803-1854), Roberta Jana Nepomuka Führera (1807-1861), Václava Emanuela Horáka (1800-1871), Ignaze Reimanna (1820-1885) a dalších.

Personál většiny farních kostelů sestával kromě kapelníka a varhaníka (př́ípadně instrumentalistů) také $\mathrm{z}$ několika sboristů. Ve větších kostelích či v biskupských chrámech sbor tvořili choralisté - tenoristé a basisté obstarávající jednohlasé pasáže a fundatisté - chlapci před mutací, zpívající sopránové a altové basy, kteří žili ve fundaci a za byt a stravu se účastnili liturgického dění. Neobvyklá nebyla ani výpomoc studentů bohosloví či chrámových kaplanů.

II.

Přirozeným mezníkem se stala první světová válka. Společenská nálada spolu se změnou hospodářských a sociálních podmínek duchovní sfeere a církevnímu životu za první republiky obecně př́iliš nepřály. Proticírkevní agitace a špatné finanční podmínky v církevních službách způsobily, že zdatní hudebníci odmítali místa na kůrech a hledali své uplatnění v hudební sféře světské. O málo lepší byla situace ve větších městech, kde si mohli varhaníci či ředitelé kưru přivydělat také ve funkcích ředitelů a učitelů hudebních škol, sbormistrů spolků, zpěváků $\mathrm{v}$ divadlech či u hudebních souborů. Ale ani zde nebyly podmínky vždy prŕíznivé. Např́klad reneschori olomouckého dómu sv. Václava Antonín Petzold (18581931), jenž měl roku 1923 na kůru k dispozici pouhé dva choralisty, jednoho varhaníka a jednu výpomocnou zpěvačku, žil ve velmi nuzných poměrech, přestože si přivydělával soukromou výukou zpěvu. „Snad se vlivní činitelé ustrnou nad nevýslovnou mojí bídou a utrpenim", napsal v jedné ze žádostí metropolitní kapitule o zvýšení platu. ${ }^{6}$ Jeho mizerné sociální postavení dokládá i skutečnost, že mu byl roku 1923 exekutory zabaven majetek.

Běžný liturgický provoz obvykle zajištoval ve většině chrámů jen varhaník, prípadně několik zpěváků. Sboristé provozovali o nedělích a svátcích jednotlivé části mešního ordinaria a propria. První světová válka v podstatě také ukončila vývoj cyrilského hnutí, přestože Obecná jednota cyrilská byla formálně zrušena

$6 \quad$ VIČAROVÁ, op. cit., s. 182. 
až v roce 1953. Myšlenkové proudy, organizační základy i kompoziční odkaz reformy však doznívaly po celou první polovinu minulého století.

V poválečném období patřili $\mathrm{k}$ nejuváděnějším skladatelům chrámové hudby autoři, jejichž kompoziční styl umně syntetizoval soudobou hudební řeč s jazykem minulosti. $Z$ nich je nutné na prvním místě jmenovat Vojtěcha Ríhovského (1871-1950), dále pak př́slušníky kompoziční školy Karla Steckra, do níž patřili: Karel Douša (1876-1944), Adolf Kramenič (1889-1953), Norbert Kubát (1863-1935), František Picka (1873-1918), Otto Albert Tichý (1890-1973), Eduard Tregler (1868-1932), Stanislav Vrbík (1907-1987), Bedřich Antonín Wiedermann (1883-1951) a Josef Winter (1870-1951). K dalším provozovaným autorům meziválečné skladatelské generace chrámové hudby patřili Josef Čapka-Drahlovský (1847-1826), Bohuslav Jeremiáš (1858-1918), Josef Klička (1855-1937), František Kolařík (1867-1927), Josef Matějů (1922-1992) a František Musil (1852-1908).

Lid se aktivně účastnil zpěvu kostelních písní mešních či př́ležitostných vydaných v Českém kancionálu Dobroslava Orla a Vladimíra Hornofa (Praha 1921), závazném v českých diecézích. V olomoucké arcidiecézi se prosadil zpěvník Boži cesta Františka Večeři-Střížovského (Olomouc 1938), v brněnské pak Cesta $k$ věčné slávě (Brno 1909).

\section{III.}

Rovněž útrapy druhé světové války značně ovlivnily postavení a interpretační podobu chrámové hudby. Kromě zhoršení ekonomických podmínek stojí za zmínku zúžení interpretační základny chrámových těles. Naopak byly posíleny pocity národní sounáležitosti, což se na mnohých kůrech projevovalo akcentací mešních skladeb českých autorů.

Po roce 1945 patřila kdysi neochvějná pozice církve ve společnosti již nadobro minulosti. Bezprostředně po druhé světové válce usilovala většina kůrů o konsolidaci a návrat $\mathrm{k}$ předválečným poměrům, tedy stabilitě personální $\mathrm{i}$ umělecké. Chrámoví hudebníci a zpěváci tak i nadále plnili svou hlavní funkci - sloužili liturgii, zvyšovali její slavnostnost a povzbuzovali zbožnost obce věrících. Umělecká kvalita hudebních produkcí přirozeně odrážela odbornou erudici a interpretační vybavenost personálu. Jeho počet odpovídal významu toho kterého chrámu. Například olomoucká katedrála zaměstnávala za časů kapelníka Gustava Pivoňky (1895-1977) dvacetičlenný smíšený sbor.?

Od čtyřicátých let se začaly $\mathrm{v}$ repertoáru mnoha kůrů objevovat skladby Jaroslava Křičky (1882-1969) a Josefa Bohuslava Foerstra (1859-1951), k jehož žákům a následovníkům patřili Emil Axman (1887-1949), Vilém Blažek (19001974), Jan Budík (1899-1974) a Antonín Janda (1891-1961). O Vánocích mnozí 
chorregenti sahali ke skladbám Janáčkových žáků, Františka Kolaříka (18671927) a Eduarda Marhuly (1877-1925).

Je také důležité připomenout, že od čtyřicátých let začala mnohá chrámová tělesa pořádat tzv. hodinky duchovní hudby, tedy autonomní koncertní produkce duchovní hudby. Teprve tehdy je totiž začaly ordinariáty povolovat. ${ }^{8}$

\section{IV.}

Důsledky odrážející se v provozu chrámové hudby po „Vítězném únoru“ 1948 jsou zřejmé: Zúžila se pěvecká základna, poklesly finanční dotace a nové kompozice vznikaly jen $\mathrm{v}$ omezeném počtu. $\mathrm{V}$ atmosféře, kdy bylo mnoho představitelů církevní hierarchie krutě vyslýcháno, nepravdivě obviněno a dlouhodobě vězněno, se stala již pouhá návštěva kostela, natož aktivní účinkování při liturgii, projevem mimořádného osobního hrdinství.

Je až překvapivé, kolik chrámových sborů v těchto ztížených podmínkách nadále pracovalo a vykazovalo téměř nezměněnou činnost. Fluktuace členů chrámových sborů byla až překvapivě nízká. Ve farních kronikách zaznamenáváme jména pěvců účastnících se chrámových produkcí i po několik desetiletí. Pravdou je, že mnohé chrámové sbory pracovaly se zažitým repertoárem a málokdy se uchylovaly ke studiu novinkového materiálu.

Provozovaný repertoár každého chrámu byl přirozeně dán množstvím a kvalitou zpěvákủ, kteř́ jej uváděli, a samozřejmě také zdatností kapelníka. V tomto smyslu přirozeně existovaly velké rozdíly mezi kostely venkovskými a městskými, mezi chrámy farními a biskupskými, ale i mezi Prahou, regionálními centry a periferií. Sledujeme-li repertoár několika pražských chrámů v padesátých a šedesátých letech, který se podařilo shromáždit Petru Bajerovi, a srovnáme-li jej s děním v centru olomoucké arcidiecéze, zjistíme, že i přirozená umělecká centra fungovala vzhledem k pražské metropoli jen jako region: Sbor svatojakubského kostela za ř́zení Josefa Hercla měl v Adventu roku 1953 v repertoáru Campanovo Rorando coeli, Palestrinovu Missu Aeterna Christi munera a Victoriovo moteto Tantum ergo. Na Vánoce zde zněla díla Františka Xavera Brixiho, Jiř́iho Ignáce Linka, Jana Lohelia Oehlschägela a Česlava Vaňury, do Nového roku pak ještě skladby Jana Ladislava Dusíka, Tomáše Norberta Koutníka, Wolfganga Amadea Mozarta, či Ondřeje Poddaného. ${ }^{9}$ Sbor katedrály sv. Víta nastudoval za vedení Otty Alberta Tichého u př́ležitosti adventních neděl v letech 1954-1961 díla Aneria Feliceho (Missa VIII toni), Ignaze Mitterera (Missa in hon. Assumptionim B. M. V.), Giovanni Pierluigiho da Palestriny (Iste Confesor), Tomáse Luise de

8 P. Hlaváček v souvislosti s děním ve Slavkově nalezl informace, že zdejší Farní cyrilská jednota uspořádala svatodušní duchovní koncert již 5. června 1922. Viz HLAVÁČEK, op. cit., s. 38. Arcibiskupská konsistoř v Olomouci však podobné akce v této době zakazovala. 
Victorii (Tantum ergo) a O. A. Tichého (Offertorium) ${ }^{10}$ Studentský sbor vedený J. Hanzlíkem v letech 1953-1955 měl v repertoáru pro adventní období Williama Byrda (Missa f moll), Palestrinu (Missa Lauda Sion) a O. A. Tichého (Missa in honorem Scti Adalberti). ${ }^{l l}$ Křížovnický sbor s A. Michlem v čele studoval $\mathrm{v}$ tomto období skladby Antona Brucknera (Missa in e moll), Františka Vladislava Heka (Missa pastoralis), Leoše Janáčka (pravděpodobně Mše Es), Licinia Reficeho (1885-1954) a Josefa Rheinbergera (1839-1901) Mše D dur op. 169). ${ }^{12}$ Sbor Panny Marie Sněžné ř́żený J. Včelákem měl v období 1955-1962 v repertoáru skladby F. X. Brixiho (pastorely), Johanna Josepha Fuxe (Missa in g moll), Andrey Gabrieliho (Missa brevis), Orlanda di Lasso (Missa Puisque j'ai perdu), Antonia Lottiho (Missa brevis), W. A. Mozarta (Missa in F) a Kamila Voborského (Missa in h moll). ${ }^{13}$

Olomoucký věřící se s tak pestrou variabilitou repertoáru přirozeně nesetkával. Rovněž si mohl nechat snad jen zdát o tom, že by při chrámové produkci, byt' slavnostní, účinkovali natolik špičkoví pěvci, jako byli Beno Blachut či Eduard Haken, kteří oživovali produkce u pražského sv. Jakuba. ${ }^{14}$

Přesto patřilo k obecným rysům doby, že mnoho chrámových kapelníků, varhaníků i zpěváků patřilo k čelným osobnostem místní hudební kultury. Tyto osobnosti umně dokázaly propojit své aktivity na poli církevním i světském. Naprŕklad v Olomouci se jednalo o stranicky prověřeného kulturního pracovníka Svatopluka Ščudlíka (1927-1981), zastávajícího funkci ředitele Parku kultury a oddechu, sbormistra Komorního pěveckého sdružení Dvořák, později smíšeného sboru Žerotín, a zároveň regenschoriho Kostela sv. Cyrila a Metoděje v Olomouci-Hejčíně a sboru Církve československé husitské, anebo o Františka Preislera (1915-1983), žáka J. B. Foerstra či Karla Douši, dirigenta olomoucké opery a zároveň varhaníka a regenschoriho hejčínského chrámu. ${ }^{15}$

Můžeme také zobecnit, že chrámová hudba velmi často spočívala v rukou intelektuální elity města. Mezi varhaníky a kostelními zpěváky často figurovali lékaři, stavební inženýři, doktoři přŕrodních věd apod., kteří se vypracovali ve velmi kvalitní a pohotové hudebníky, ač mnohdy začínali jako samoukové.

K čelným skladatelům věnujícím se chrámové hudbě patřili ve druhé polovině 20. století Jarmil Burghauser (1921-1997), Petr Eben (1929-1927), Jan Hanuš (1915-2004), Zdeněk Pololáník (1935) nebo Karel Sklenička (1933), jejich řady doplnili Jan Maria Dobrodinský (1925), Emil Hába (1900-1982), Jiř́ Laburda

\footnotetext{
10 Ibid., s. 38.

11 Ibid., s. 39.

12 Ibid., s. 40.

13 Ibid., s. 41 .

14 Ibid., s. 62.

15 O něm více viz: ŠTĚDROŇ, Bohumír. Preisler, František. In Československý hudebni slovník osob a institucí. sv. 2. G. Černušák - B. Štědroň - Z. Nováček (eds.), Praha: Státní hudební vydavatelství, 1965, s. 364.
} 
(1931), Zdeněk Lukáš (1928-2007), Otmar Mácha (1922-2006), Antonín Tučapský (1928), František Xaver Thuri (1939) či Zdeněk Zouhar (1927-2011).

\section{V.}

K velkým změnám došlo také uvnitř katolické církve. Tváŕí liturgie se mimo jiné zabýval Pius XII., jehož list Oecumenici declaratio authentica z roku 1950 posloužil jako předloha $\mathrm{k}$ jednání II. vatikánského koncilu (1962-1965). Z šestnácti dokumentů se hudbě věnuje kapitola šestá „Sacrosanctum Concilium“. Otázkami prosazování závěrů II. vatikánského koncilu do hudební praxe se zaobíral dokument Musicam sacram z roku 1967.

Koncil vnesl do římsko-katolického ritu řadu převratných změn: Dosud uplatňované hlavní typy liturgického obřadu, mši slavnou, zpívanou a tichou, vystř́ídaly mše s účastí či bez účasti lidu. Missa mundi probíhala za „živého a aktivního" podílu celého shromáždění věřících. Latina mohla být nahrazena národním jazykem. Přizpůsobení podoby chrámové hudby církevní obci mnohdy vedlo k poklesu její umělecké úrovně a upozadění dosud výsadní funkce chrámových sborů.

V českém prostředí byla vytvořena čtyři mešní ordinaria: Karla Břízy (19262001), Petra Ebena, Josefa Olejníka (1914-2009) a Zdeňka Pololáníka. Lidu byly také určeny písně parafrázující některé části ordinaria a písně ve funkci propria vydané v Kancionálu (1973) Ladislava Simajchla, na nějž navázal Kancionál, společný zpěvník českých a moravských diecézi (1992) Oldřicha Ulmana.

Ohledně podoby zpěvu kněze a lidu se rozvinula obsáhlá diskuse. Dilema se týkalo toho, zda mají být dosud uplatňované chorální partie nadále zachovány a podloženy národními jazyky, ač to nebude zcela vyhovovat jejich deklamaci ani rytmu, nebo zda mají vzniknout nové melodie, zohledňující př́izvuk a dikci mateřštiny. V našem prostředí tyto rozdílné př́stupy reprezentovaly sedmdesátistránkové Jednoduché chorální nápěvy nového českého Ordo Missae Františka Holíka vydané roku 1969 v Brně na straně jedné a devětačtyřicetistránkový Návrh na nové nápěvy kněze a Božího lidu Josefa Olejníka vzniklý v Olomouci 1969 na straně druhé. Zatímco v zahraničí se většinou přiklonili k možnosti první, tedy podkládali tradiční melodie novými texty, v našem prostředí zvítězila linie druhá, prosazovaná právě Josefem Olejníkem. ${ }^{16}$ Tento absolvent ř́mského Pontificio Istituto di Musica Sacra, kde získal titul „magistr gregoriánského zpěvu“ a „licenciát kompozice posvátných zpěvưu, a pedagog liturgického zpěvu na Cyrilo-

16 Podrobněji viz: KOMÁREK, Karel. P. Mgr. Josef Olejnik, kněz a skladatel liturgické hudby. Olomouc, 2001; MUSIL, Jiř́. K osmdesátinám doc. P. Mag. J. Olejníka. In AUPO, faculta paedagogica, Hudebni véda a výchova 7, Musica V. Olomouc, 1996; PAVLACKÁ, Jana. Josef Olejník a jeho prínos v oblasti liturgické hudby po II. vatikánském koncilu. Diplomová práce, CMTF UP v Olomouci, Olomouc, 1996; ROZKOVCOVÁ, Radka. P. Josef Olejník a jeho sborové úpravy lidových písní a koled. Diplomová práce, PdF UP v Olomouci, Olomouc, 2006. 
metodějské teologické fakultě v Olomouci (1945-1950, 1968-1973, 1990-1996) se v celorepublikovém kontextu prosadil zejména jako autor dodnes provozovaných děl: ordinaria Česká mše z Andělské Hory (1966), zpívaného dialogu kněze a lidu před prefací Návrhu na nové nápěvy kněze a Božího lidu (1969), Žaltáře a Responzoriálnich žalmů pro neděle svátky, památky a mše spojené s určitými obřady (1995).

Závěry koncilu se často nesetkávaly s přízní a pochopením chrámových hudebníků, nebot' ti si museli zvykat na odlišný repertoár i na nový chod liturgie. Novoty byly rovněž přijímány s menším či větším časovým odstupem. Zatímco např́íklad v olomoucké katedrále proběhl již 8 . dubna 1966 celý obřad v českém jazyce, již zmíněný F. Preisler se dle pamětníků loučil s hudebními zvyklostmi uplatňovanými před II. vatikánským koncilem velmi těžce a ještě v první polovině sedmdesátých let doprovázel hejčínské liturgie latinskými mešními cykly. ${ }^{17}$ Teprve při oslavách patronicia chrámu 5. července 1975 zde byl zaveden nový způsob liturgie.

K přímým důsledkům koncilu patř́i také vznik mládežnických schol, které prováděly tzv. rytmické mše s doprovodem kytary a flétny, př́ípadně jiných nástrojů, jejichž hudební složka reagovala na rozvoj moderní populární hudby. Scholy se s chrámovými sbory při liturgii obvykle stř́daly.

V neposlední řadě II. vatikánský koncil umožnil dále otevř́ít kostely širší hudební veřejnosti. Stalo se tak prostřednictvím nově zakládaných festivalů. Například v Olomouci se jednalo o Mezinárodní varhanní festival (poprvé v roce 1969) využívající rekonstruované slavné Englerovy varhany u sv. Mořice, Podvečery u varhan (1977) pořádané u Panny Marie Sněžné a o Nokturna (1978) konaná v katedrále.

VI.

Poslední velký mezník ve vývoji české chrámové hudby souvisí s tzv. sametovou revolucí 1989. Na jedné straně začala vznikat nová chrámová tělesa a obrovský boom zaznamenala i skladatelská produkce duchovní hudby, na straně druhé se mnohé chrámové sbory rozpadly nebo se potýkaly s odlivem mladých pěvců, kteř́ začali nalézat seberealizaci v „atraktivnějších“ hudebních žánrech.

Výjimkou potvrzující pravidlo byl studentský smíšený sbor Střípky fungující při chrámu Panny Marie Sněžné v Olomouci - sídle Studentské farnosti Univerzity Palackého -, který vznikl u př́ležitosti setkání mládeže se Svatým Otcem Janem Pavlem II. na Svatém Kopečku roku 1995. Schola nejprve doprovázela studentské bohoslužby, později hostovala na mnoha významných katolických akcích, jako např. Setkání katolické mládeže, Studentský Velehrad, posléze zajistila hudební doprovod setkání papeže Jana Pavla II. s mládeží v Hradci Králové

17 Pamětni kniha farnosti Olomouc-Hejčín. Je uložena na Římskokatolickém farním úřadě v Olomouci-Hejčíně. 
roku 1997 a byla zvolena jako hlavní hudební doprovod českého národního centra v průběhu Světového setkání mládeže v Římě roku 2000. Při těchto akcích sbor disponoval vlastní doprovodnou kapelou rrízenou Josefem Fojtou, členem souboru Hradištan, bicistou Dama-dama a Filharmonie Bohuslava Martinů Zlín, a spolupracoval třeba s Jiř́m Pavlicou či Martou Kubišovou. Těleso natočilo tři profilová CD (Stř́pky, Strrípky II, Abba Otče), objevovalo se v přenosech Rádia Proglas i Televize Noe a část jeho členů se podílela na vzniku alba Na cestě (ve spolupráci s komorním sborem Anima Una). V jeho repertoáru figurovaly písně křest’anských zpěvníků či autorské skladby členů sboru. ${ }^{18}$

V př́ipadě většiny kostelů se ustálilo se, že liturgický provoz ve všední dny zajišt'oval pouze varhaník. O nedělích a svátcích jej doplnili sólisté, prŕípadně chrámový sbor či schola. Zatímco chrámové sbory se zaměřily na provozování tradičnějšího hudebního repertoáru založeného na duchovních skladbách různých slohových epoch, repertoár schol, obvykle doprovázených kytarami, př́ipadně dalšími rytmickými nástroji, vycházel ze sborníkủ Hosana, Koinonia či zpěvů různých katolických komunit.

Chrámoví hudebníci získali volné pole působnosti v pořádání vlastních koncertních vystoupení či organizování přehlídek chrámových sborů (Sborování v Boskovicích, Laudate musicam v Olomouci), začali se pouštět do společných uměleckých projektů, pohostinských vystoupení a podobně. Mnoho těchto př́ležitostí získalo také benefiční ráz.

Ve snaze zvýšit odbornou kvalifikaci chrámových varhaníků byla roku 1993 založena jednota Musica sacra v Brně, připomeňme rovněž existenci církevních konzervatoří v Kroměříži (1990, pak v Olomouci) nebo v Opavě (1999) či Olomouci (1990). Na interpretaci gregoriánského chorálu je zaměřena Schola gregoriana pragensis (1987) či brněnská Svatomichalská schola (1994).

V neposlední řadě zahájili chrámoví hudebníci spolupráci se světskými hudebními tělesy a představiteli dalších oblastí hudebního života. Lesk liturgických obřadů přirozeně také zvýšila prríležitostná vystoupení známých hudebních osobností. V této podobě vešla katolická chrámová hudba do 21 . století.

\section{Závěrem}

Ani ve 20. století nepřestala chrámová hudba plnit svou hlavní roli a zároveň se podílela na kulturním životě měst a obcí. Mnoho sborů obhájilo svou existenci ve složitých společenských a kulturních dějích minulého století. Vlastní umělecká kvalita chrámových těles, zdánlivě přímo úměrná historickému i lokálnímu významu toho kterého chrámu, vždy odrážela erudici a interpretační vybavenost chrámových hudebníků. Ti často patřili k čelným osobnostem místní hudební kultury. Repertoár tvořily jak kompozice soudobých autorů, tak představitelů starších historických epoch. Lid se bohoslužeb účastnil prostřednictvím mešních

Rozhovor autorky studie s Pavlem Kociánem se uskutečnil 22. 10. 2012. 
či prríležitostných písní, po II. vatikánském koncilu také zpěvem mešního ordinaria a propria. Chrámová hudba tak nadále zůstala svébytným uměleckým a hudebním fenoménem.

Eva Vičarová (eva.vicarova@upol.cz) vystudovala muzikologii (Mgr., 1996), žurnalistiku (Bc., 1996) a teorii a dějiny hudby (Ph.D., 1999) na Filozofické fakultě Univerzity Palackého v Olomouci, kde se rovněž habilitovala (Doc., 2013). Absolvovala semestrální studijní pobyty na Royal Holloway College, University of London (1996) a na Wiener Universität (1998). Od roku 2000 působí na Katedře muzikologie Filozofické fakulty Palackého Univerzity v Olomouci, kde vyučuje hudební historiografii, hudební analýzu, hudební kritiku a hudební didaktiku. Vědecky se specializuje na vojenskou hudbu (kniha Rakouská vojenská hudba 19. století a Olomouc, Olomouc 2002), chrámovou hudbu (kniha Hudba v olomoucké katedrále, 1872-1985, Olomouc 2012) a na dějiny olomoucké hudební kultury.

\section{ABSTRACT \\ TO THE HISTORY OF CHURCH MUSIC IN CZECH LANDS DURING 20TH CENTURY}

Music in Czech catholic churches during the 20th century was influenced by various styles of composition plus the function of both artificial and also popular music. In addition to these, other main influences included aspects of European and contemporary church history, such as: the Motu proprio (1903) of Pope Pio X; World Wars I and II; the start of the totalitarian system in 1948; the results of the 2nd Vatican Council; and the fall of communism in 1989. This study presents aspects of repertoire, the most important composers, the organisation of church choirs as well as the concert activities of church musicians.

\section{Key words}

church Music, 20th century, the history, Motu proprio 1903, 2nd Vatican Council, the Czech lands, World War I, World War II, 1948, 1989, Olomouc, composers, choirmasters, organists, singers

\section{Bibliography}

BAJER, Petr. Přispěvek k dějinám chrámové hudby v Čechách ve 2. polovině 20. století. Seminární práce, Ústav hudební vědy FF UK, Praha, 2005.

ČALA, Antonín. Duchovní hudba. Olomouc 1946.

FELLERER, Karl Gustav. Geschichte der katholischen Kirchenmusik. Kassel: Bärenreiter, 1976.

FUKAČ, Jiří. Církevní hudba. In Slovník české hudebni kultury. Jiří Fukač - Jiří Vysloužil (red.), Petr Macek (ed.). Praha: Editio Supraphon, 1997, s. 98-100.

HERBST, Wolfgang. Musik in der Kirche. In Die Musik in Geschichte und Gegenwart. Sachteil, sv. 6, s. 715-727.

HLAVÁČEK, Petr. Hudba v chrámu Vzkříšení Páně ve Slavkově u Brna do poloviny 20. století. In Hudba v Olomouci a na středni Moravě II. Morava a svět: Umění v otevřeném multikulturním prostoru. Eva Vičarová (ed.). Olomouc, 2008, s. 7-44.

KIRSCH, Winfried. Caecilianismus. In Die Musik in Geschichte und Gegenwart. Sachteil, Bd. 2, 1995, s. 317-326.

KOMÁREK, Karel. P. Mgr. Josef Olejník, kněz a skladatel liturgické hudby. Olomouc, 2001. 
KÜFHABEROVÁ, Božena. Cecilianismus. In Slovník české hudebni kultury. Jiří Fukač - Jiří Vysloužil (red.), Petr Macek (ed.). Praha: Editio Supraphon, 1997, s. 90.

LEMACHER, Heinrich - FELLERER, Karl Gustav. Handbuch der katolischen Kirchenmusik. Essen 1949.

MUSIL, Jiří. K osmdesátinám doc. P. Mag. J. Olejníka. In AUPO, faculta paedagogica, Hudebni věda a výchova 7, Musica V. Olomouc, 1996.

NEDĚLKA, Michal. Mše v soudobé české hudbě, Praha 2005.

NOVÁKOVÁ, Marcela. Katolická liturgická hudba v 50. letech 20. století. Seminární práce, Ústav hudební vědy FF UK, Praha, 2005.

NOVÁKOVÁ, Marcela. Katolická liturgická hudba v kontextu hudebního vývoje a politických změn po druhé světové válce. Diplomová práce, Ústav hudební vědy FF UK, Praha, 2008.

PAVLACKÁ, Jana. Josef Olejník a jeho prrinos v oblasti liturgické hudby po II. vatikánském koncilu. Diplomová práce, CMTF UP v Olomouci, Olomouc, 1996.

ROZKOVCOVÁ, Radka. P. Josef Olejnik a jeho sborové úpravy lidových písni a koled. Diplomová práce, PdF UP v Olomouci, Olomouc, 2006.

SEHNAL, Jiří. Chrámová hudba na Moravě od cyrilské reformy do současnosti. Opus musicum, 2001, roč. 33, č. 4, s. 4-18.

SEHNAL, Jiří. Stručný přehled dějin katolické chrámové hudby. Rosice: Glorie, 1999.

SILNÁ, Ingrid. Hudba ve farním kostele sv. Václava v Tovačově. Olomouc, 2009.

SLAVICKÝ, Tomáš. K vývoji české kostelní písně v první polovině 20. století. In 70. výročie vydania Jednotného katolického spevníka. Zborník príspevkov z muzikologickej konferencie. Trnava - Bratislava 2008, s. 78-101.

SMUTNÝ, Pavel. Historické kořeny cecilianismu. K významu reformního hnutí. Opus musicum, 1997, roč. 29, č. 3, s. 138-148.

SMUTNÝ, Pavel. Liturgická hudba a muzikologie. Opus musicum, 1996, roč. 28, č. 2, s. 61-63.

ŠTĚDROŇ, Bohumír. Preisler, František. In Československý hudebni slovník osob a institucí. sv. 2. G. Černušák - B. Štědroň - Z. Nováček (eds.), Praha: Státní hudební vydavatelství, 1965, s. 364.

VIČAROVÁ, Eva. Hudba v olomoucké katedrále, 1872-1985, Olomouc: Univerzita Palackého, 2012. 
